\title{
Kecerdasan Adversitas sebagai Salah Satu Faktor Penentu dalam Mengoptimalkan Pencapaian Target Kompetensi Asuhan Kebidanan
}

\author{
Made Juliani* \\ Fakultas Olahraga dan Kesehatan Universitas Pendidikan Ganesha, Singaraja, Bali
}

\section{A R T I C L E I N F O \\ Article history: \\ Received 19 February 2018 \\ Received in revised form 10 March 2018 \\ Accepted 12 April 2018 \\ Available online 25 May 2018

\begin{tabular}{lr}
\hline Kata Kunci: & \\
Kecerdasan & Adversitas, \\
Pencapaian & target \\
kompetensi & asuhan \\
kebidanan &
\end{tabular} \\ Keywords: \\ Adversity Quotient, \\ Achievement of midwifery \\ care competency targets}

\begin{abstract}
A B S T R A K
Penelitian ini bertujuan untuk mengetahui hubungan antara kecerdasan adversitas dengan pencapaian target kompetensi asuhan kebidanan pada mahasiswa semester VI Jurusan Kebidanan Fakultas Olahraga dan Kesehatan dengan menggunakan rancangan penelitian korelasional. Populasi penelitian adalah seluruh mahasiswa semester VI sebanyak 82 orang, sampel diambil sebanyak 82 orang. Data yang diperoleh diolah dengan menggunakan analisis regresi liner sederhana. Hasil penelitiannya adalah : (1) Kecerdasan Adversitas pada mahasiswa berada pada kategori sangat tinggi, (2) pencapaian target kompetensi asuhan kebidanan berada pada kategori sangat baik, dan (3) terdapat hubungan yang signifikan antara kecerdasan adversitas denagn pencapaian target kompetensi asuhan kebidanan.
\end{abstract}

\section{A B S T R A C T}

This research is aimed to find out the correlation between adversity Quotient and the Achievement of midwifery care competency target in Semester VI Midwifery Department of Faculty of Sport and Health by using correlational research design. The population of the study was 82 students in semester VI, 82 samples were taken. The data obtained are processed using simple liner regression analysis. The results of the research were: (1) Adversity Quotient in the students was very high in category, (2) the Achievement of midwifery competency target was very good category, and (3) there was a significant correlation between adverse Quotient and attainment of midwifery competence target.

\footnotetext{
* Corresponding author.

E-mail addresses: nersmdjuliani@gmail.com (Made Juliani)
} 


\section{Pendahuluan}

Seiring dengan kemajuan tehnologi dan perubahan serta perkembangan industri yang pesat yang tercermin dalam globalisasi dan perdagangan bebas yang telah dimulai tahun 2003 melalui Asean Trade Area (AFTA), selanjutnya dengan kerangka World Trade Organization (WTO) tahun 2020 bagi negara berkembang dan tahun 2010 bagi negara maju mengakibatkan tuntutan akan kualitas dan profesionalisme kerja disetiap sektor makin tinggi (Pusdiknakes, 2005). Hanya individu yang mampu bersaing yang dapat berbicara dalam era globalisasi. Untuk itu setiap individu harus memiliki kompetensi yang handal dalam berbagai bidang, kompetensi tersebut dapat dicapai melalui berbagai pengalaman praktik. Pengalaman pembelajaran praktik (laboratorium kelas, rumah sakit, komunitas dan unit pelayanan kesehatan lainnya) merupakan bagian penting dalam program pendidikan kesehatan. Hal tersebut memberikan pengalaman yang berharga bagi mahasiswa dalam menerapkan ilmu pengetahuan pada situasi nyata. Melalui pembelajaran praktik mahasiswa mendapat kesempatan untuk mengembangkan kemampuannya (Pusdiknakes, 2005).

Mata kuliah Praktek Klinik kebidanan ini memberikan kemampuan kepada mahasiswa untuk melaksanakan praktek klinik pada mahasiswa dalam memberikan asuhan kebidanan dengan pendekatan manajemen kebidanan kasus normal pada kehamilan, persalinan, ibu post partum, neonatal, bayi dan balita sesuai dengan tingkat kebutuhan. (Kurikulum, 2012). Gambaran kompetensi mahasiswa ini dapat diketahui melalui Ujian Tahap yang diselenggarakan oleh institusi (Pusdiknakes, 2004). Ketrampilan yang diperoleh mahasiswa secara langsung dapat menjadi bekal bagi mahasiswa untuk mencapai kompetensi sebagai seorang bidan sehingga dapat bersaing dengan lulusan kebidanan yang lain untuk memperoleh kesempatan kerja.

Target kompetensi yang diterapkan pada lingkungan pendidikan Prodi D3 kebidanan pada FOK Undiksha, diberlakukan bagi mahasiswa semester V dan VI. Target praktik yang harus dipenuhi yaitu 40\% dari praktik klinik kebidanan 1, 40\% praktik klinik kebidanan 2 dan $20 \%$ praktik klinik kebidanan 3. Idealnya target-target ini tercapai sesuai dengan harapan institusi pendidikan, karna dengan mengetahui pencapaian target tersebut berarti mahasiswa telah mampu mencapai keterampilan sesuai kompetensinya. Target memiliki arti sangat penting karna dapat menentukan kelulusan setiap mahasiswa yang menempuh pendidikan vokasional khususnya kebidanan. Berdasarkan hasil rekapitulasi target yang telah dilaksanakan oleh tim praktik klinik kebidanan, diproleh belum keseluruhannya dapat tercapai sesuai dengan harapan. Rata-rata pencapaian target mahasiswa di PK1 sekitar 10-20\%, PK2 sekitar 15-25 \%, dan PK3 20-30\%. Hal ini kemungkinan dipengaruhi oleh motivasi mahasiswa saat pelaksanaan praktik klinik kebidanan, kepercayaan diri dan ketahanan mahasiswa dalam melaksanakan tugas dan kewajiban yang diberikan oleh institusi. Ketahanan mahasiswa dalam menghadapi masa-masa sulit inilah yang sering dikaitkan dengan kecerdasan adversitas.

Keberhasilan seorang peserta didik dalam menyelesaikan target prakatik ditentukan oleh kecerdasan adversitas seorang mahasiswa tersebut, dalam mencapai target praktik yang telah ditentukan. Kecerdasan adversitas seseorang merupakan salah satu faktor penentu yang mempengaruhi seseorang dalam mengatasi masalah dan juga sangat menentukan keberhasilan dalam menempuh pendidikan, seorang mahasiswa yang memiliki tingkat kecerdasan intelektual yang baik belum tentu menjadikan keberhasilan dalam belajar. Menurut Stolz (2000) menyatakan bahwa kecerdasan adversitas (Adversity Quotient) merupakan kemampuan seseorang untuk mampu bertahan menghadapi kesulitan dan mampu mengatasi kesulitan tersebut, serta mampu melampui harapan-harapan atas kinerja dan potensinya.

Kesuksesan seseorang terutama ditentukan cara dia menjelaskan atau merespon peristiwaperistiwa dalam kehidupannya. Mereka yang merespon kesulitan sebagai sesuatu yang sifatnya tetap, internal dan dapat digeneralisasi kebidang-bidang kehidupan lainnya cendrung menderita disemua bidang kehidupan. Mereka yang menanggapi situasi-situasi sulit sebagai sesuatu yang sifatnya eksternal, sementara, dan terbatas cendrung menikmati banyak manfaat, mulai dari kinerja sampai kesehatan(Stolz ,2000).

Prodi D3 Kebidanan pada FOK Undiksha menetapkan ketentuan bahwa mahasiswa harus mampu menguasai ketrampilan sesuai dengan standart kompetensi yang telah ditetapkan dalam setiap praktek klinik kebidanan. Ketrampilan yang dimiliki oleh setiap mahasiswa tidak sama. Berdasarkan studi awal peneliti memperoleh temuan bahwa masih terdapat mahasiswa yang belum dapat mencapai ketrampilan dalam memberikan asuhan kebidanan pada ibu hamil, bersalin, nifas dan lainnya sesuai kompetensi yang ditetapkan dalam pelaksanaan praktik klinik kebidanan. Oleh karena itu diperlukan kecerdasan untuk mampu bertahan menghadapi kesulitan dan kemampuan untuk mengatasinya. Oleh karena itu peneliti tertarik melakukan penelitian dengan judul "Adversity Quotient sebagai salah satu faktor penentu mengoptimalkan pencapaian target kompetensi mahasiswa" 


\section{Metode}

Penelitian ini merupakan jenis penelitian asosiatif dengan menggunakan pendekatan crossectional yaitu suatu penelitian yang dilakukan untuk melihat hubungan antara variabel independen (kecerdasan adversitas) dengan variabel dependen (pencapaian target kompetensi) dimana data penelitian diambil sekaligus dalam waktu yang bersamaan. Populasi yang dimaksud pada penelitian ini adalah seluruh mahasiswa Jurusan Kebidanan semester VI yang telah mengikuti Praktek Klinik Kebidanan III. Peneliti memilih populasi tersebut dengan pertimbangan mahasiswa tersebut telah melewati kegiatan Praktek Klinik Kebidana III dan penghitungan ketercapaian target melalui Pembimbing Akademik namun hasil yang dicapai peserta didik dirasa belum maksimal

\section{Hasil dan Pembahasan}

Berdasarkan hasil perhitungan maka dapat diketahui:

Pertama, Data kecerdasan adversitas diperoleh melalui angket terdiri dari 40 butir pertanyaan dan jumlah responden 82 mahasiswa. Hasil analisis menunjukkan harga rata-rata (mean) $=82,28$, nilai tengah $($ median $)=83$, modus $($ mode $)=74$, simpangan baku (standar deviation $)=5,75$, skor minimum $=69$, skor maksimum $=96$, kemiringan (skewness $)=0,071$.

Kedua, Data hasil target kompetensi kebidanan diambil dengan menghitung pencapaian target kompetensi kebidanan pada akhir praktek kebidanan dengan jumlah responden 82 mahasiswa. Hasil analisis menunjukkan harga rata-rata $($ mean $)=76,35$, nilai tengah $($ median $)=75$, modus $($ mode $)=78$, simpangan baku (standar deviation $)=11,36$, skor minimum $=55$, skor maksimum $=100$, kemiringan (skewness) $=0,123$.

Ketiga, Pengujian signifikansi bertujuan untuk mengetahui keberartian variabel kecerdasan adversitas terhadap pencapaian kompetensi. Hipotesis yang diuji kecerdasan adversitas berkontribusi positif terhadap pencapaian target kompetensi asuhan kebidanan pada mahasiswa Jurusan Kebidanan Undiksha. Uji signifikansi menggunakan uji t, berdasarkan hasil uji t diperoleh $t_{\text {hitung }}$ sebesar 3,476. Nilai $t_{\text {tabel }}$ sebesar 1,66 pada taraf signifikansi $5 \%$, maka $t_{\text {hitung }}$ lebih besar dari $t_{\text {tabel }}(3,476>1,66)$ atau sig $(0,000<0,05)$ maka hipotesis nol $\left(\mathrm{H}_{0}\right)$ ditolak dan hipotesis alternatif $\left(\mathrm{H}_{\mathrm{a}}\right)$ diterima. Berdasarkan pengujian ini kecerdasan adversitas mempunyai kontribusi yang signifikan terhadap pencapaian target kompetensi asuhan kebidanan pada mahasiswa Jurusan Kebidanan Undiksha

Hasil penelitian ini telah menemukan bahwa terdapat kontribusi positif dan signifikan antara kecerdasan adversitas terhadap pencapaian target kompetensi asuhan kebidanan pada mahasiswa Jurusan Kebidanan Undiksha

\section{Simpulan dan Saran}

Berdasarkan pembahasan yang sudah dibuat dari hasil penelitian yang dilakukan maka dapat disimpulkan sebagai berikut 1) terdapat terdapat kecenderungan semakin baik kecerdasan adversitas mahasiswa maka semakin baik pencapaian target kompetensi mahasiswa, 2) Sebaliknya semakin rendah kecerdasan adversitas mahasiswa, maka semakin rendah pencapaian target kompetensi mahasiswa, dan 3) Dengan memiliki kemauan untuk maju dan kritis dengan keadaan mahasiswa tersebut akan berpikir untuk lebih mendalami bidang penguasaan kompetensi yang dimilikinya. Melatih diri dengan berdisiplin sejak dini bisa menjadi langkah awal untuk meningkatkan kecerdasan adversitas.

Berdasarkan hasil penelitian dan simpulan yang telah dilakukan, beberapa saran yang dapat dikemukakan terkait dengan hasil penelitian dan simpulan di atas, yaitu sebagai berikut. Pertama, disarankan Lembaga pendidikan dalam hal ini Jurusan sebaiknya tidak hanya mengedepankan kecerdasan intelektual, namun juga harus memperhatikan kecerdasan adversitas mahasiswa. Dosen sebaiknya melatih mahasiswa untuk melatih kecerdasan adversitas mahasiswa misalnya memberi pembelajaran berbasis masalah dengan pemecahan dari mahasiswa sendiri secara tepat dan cepat, dosen menumbuhkan rasa percaya diri mahasiswa untuk bangkit dari kegagalan dengan memberi motivasi, mahasiswa dilatih untuk mengambil resiko tinggi, pantang menyerah dalam menghadapi berbagai macam tingkatan kesulitan Kedua, Mahasiswa sebagai peserta didik sebaiknya meningkatkan penguasaan kompetensi keahlian dengan meningkatkan kecerdasan adversitas dan termotivasi untuk mendapatkan target asuhan sesuai dengan tagihan dari institusi. Mahasiswa dapat mengoptimalkan dalam mengikuti kegiatan praktek ekstra diluar waktu praktek klinik sehingga mampu meningkatkan kematangan berpikir, kemampuan kerjasama, berkomunikasi, tanggungjawab, kemampuan adaptasi dengan lingkungan, dan ambisi untuk maju. 


\section{Daftar Rujukan}

Arikunto, Suharsimi. 2013. Prosedur Penelitian : Suatu PendekatanPraktik Cetakan. 15. Jakarta : Rineka Cipta.

Asweni, Resti Khairani. 2013. Korelasi Antara Konsep Diri Sosial Dengan Hubungan Sosial. Jurnal Ilmiah Konseling. Jurusan Bimbingan dan Konseling FIP UNP.

Badan PPSDM. 2013. Pedoman Kurikulum DIII Kebidanan. Jakarta.

Depkes RI. 2012. Kurikulum Pendidikan D-III kebidanan. Jakarta.

Desmita. 2013. Psikologi Perkembangan.Bandung : PT. Remaja Rosdakarya.

Dharma, Kelana Kusuma. 2011. Metodologi Penelitian Kperawatan : Panduan Melaksanakan dan Menerapkan.

Hsil Penelitian. Cetakan 1. Jakarta : CV. Trans Info Medika.

Hidayat. 2011. Metode penelitian keperawatan dan teknik analisa data. Jakarta :Salemba Medika.

Irawati, Nany dan Nurama Hajat. 2012.Hubungan antara konsep diri (Self Esteem) Dengan Prestasi Belajar Pada Siswa SMKN 48 di Jakarta44 Timur. Jurnal. Jakarta : Universitas Negeri Jakarta.

Kepmenkes No. 369/ III/ 2007 Tentang Standar Kompetensi Bidan Indonesia. Jakarta.

Kerlinger, Fred N. 1990. Asas-Asas Penelitian Behavioral. Terjemahan Landung R.Simatupang. Foundation of Behavioral Research. 1973. Yogyakarta. Gadjah Mada University Press.

Koyan,W.2007. Statistik Terapan (Teknik Analisis Data Kuantitatif). Buku Ajar Singaraja: Universitas Pendidikan Ganesha.

Makmun, Abin Syamsuddin. 2004.Psikologi Kependidikan. Bandung: PT. Remaja Rosdakarya.

Mitchell, D. (2004). Stress, coping, and appraisal: A test of the goodnes-of-fit hypothesis. Ohio: Ohio University Press.

Nazir,M.2009. Metode Penelitian. Cetakan Ketujuh. Bogor : Penerbit Ghalia Indonesia.

Notoatmodjo, Soekidjo. 2010. Metodologi penelitian kesehatan. Jakarta : PT.Rineka Cipta.

Pusdiknakes. 2004. Petunjuk Teknis Ujian Tahap. Jakarta: Departemen Kesehatan.

Pusdiknakes. 2005. Pedoman penilaian pencapaian kompetensi pendidikan tenaga kesehatan. Jakarta: Departemen Kesehatan.

Redjeki, Sri. 2013. Membangun Konsep Diri Positif Pada Anak. Jurnal. Semarang : FIP IKIP Veteran Semarang.

Rola, Fasti. 2006. Hubungan Antara Konsep Diri Dengan Motivasi Berprestasi Pada Remaja. Skripsi. Program Studi Psikologi: Universitas Sumatera Utara.

Safaria. 2004. Tes Kepribadian. Yogyakarta:Amara Books .

Sarwono, Sarlito W. 2011. Psikologi Remaja. Jakarta: PT RajaGrafindo Persada.

Slameto.2003. Belajar dan Faktor-Faktor yang mempengaruhinya. Jakarta :Rineka Cipta. 
Soemanto, W. 2012. Psikologi Pendidikan.Jakarta : Rineka Cipta

Sugiyono. 2014. Metode Penelitian Kuantitatif, Kulaitatif, dan R \& D. Bandung : Alfabeta.

Suliswati, S.Kep, M. Kes. 2005. Konsep Dasar Keperawatan Kesehatan Jiwa. Cet 1. Jakarta : EGC

Sulastri, Susi Sri. 2012. Pengaruh Konsep Diri dan Kebiasaan Belajar terhadap Hasil Belajar Akuntansi Siswa Kelas XI IPS Madrasah Aliyah Negeri Yogyakarta II Tahun Ajaran 2011/2012. Jurnal.Yogakarta : Universitas Negeri Yogyarta.

Sumardiono, Hendrik Dwi. 2013. Pengaruh Kesiapan Untuk Berubah Dan Motivasi Belajar Terhadap Prestasi

Stoltz, P.G. (2000). Adversity quotient, mengubah hambatan menjadi peluang. Jakarta: Grasindo.

Sumiati, Eis. 2012. Pengetahuan dan Sikap Remaja Tentang Idenitas Diri Remaja Pada Siswa SMA Kartika Medan. Jurnal. Medan : Universitas Sumatera Utara

Sunaryo. 2004. Psikologi Untuk Keperawatan. Jakarta: Penerbit Buku Kedokteran EGC.

Suroso dan Herlan Praktikto. 2012. Kemetangan Emosi, Konsep Diri, dan Kenakalan Remaja. Jurnal. Surabaya : Universitas 17 Agustus 1945

Stoltz, Paul G (2002). Adversity Quotient Mengubah Hambatan Menjadi Peluang, Jakarta : PT Grasindo.

Stuart, G. W. 2007. Buku Saku Keperawatan Jiwa . Edisi 5. Jakarta. EGC.

Sobur. 2006. Psikologi umum. Bandung : Pustaka Setia.

Syah. M. 2009. Psikologi belajar. Jakarta : Bumi Aksara.

Winkel. 2006. Psikologi Pendidikan dan Evaluasi Belajar. Jakarta: PT. Gramedia 